Rapid Communications

\title{
Pyridinium-based Task-specific Ionic Liquid with a Monothioether Group for Selective Extraction of Class $b$ Metal Ions
}

\author{
Kenji Chayama, ${ }^{\dagger}$ Yuki Sano, and Satoshi Iwatsuki ${ }^{\dagger}$ \\ Department of Chemistry, Konan University, 8-9-1 Okamoto, Higashinada, Kobe 658-8501, Japan
}

\begin{abstract}
A pyridinium-based task-specific ionic liquid (TSIL) with a monothioether group, [3-TPPy][ $\mathrm{NTf}_{2}$ ], extracted typical class $b$ metal ions, such as $\operatorname{Ag}(\mathrm{I}), \mathrm{Cu}(\mathrm{I}), \mathrm{Pd}(\mathrm{II})$, and $\mathrm{Pt}(\mathrm{II})$, in high selectivity. It was found that the composition ratio of the extracted $\mathrm{Ag}(\mathrm{I})$ and $\mathrm{Cu}(\mathrm{I})$ species depended on the TSIL concentration, and that TSIL extracted these metal ions through mono-S-coordinated complex formation at low TSIL concentrations. [3-TPPy] $\left[\mathrm{NTf}_{2}\right]$ can be recycled in the extractionrecovery process, which is of a great advantage for practical use in environmentally benign separation methods.
\end{abstract}

Keywords Task-specific ionic liquid, extraction, thioether, class $b$ metal ion, precious metals, green sustainable chemistry

(Received October 5, 2015; Accepted October 17, 2015; Published November 10, 2015)

\begin{abstract}
A substantial number of task-specific ionic liquids (TSILs), i.e., ionic liquids (ILs) incorporating functional groups in their composite ions, have been explored in the past decade as new environmentally benign multi-functional materials, e.g., extraction media of targeted species, ${ }^{1,2}$ synthetic media for catalyses, ${ }^{3,4}$ etc. In general, TSILs for the selective extraction of metal ions have functional group(s) involving donor atom(s) to extract the targeted metal ion through metal complex formation. Among studies on the extraction behaviors of metal ions by TSILs, thioether-functionalized TSILs are rare; (a) an imidazolium-based TSIL having the 3-thiapentyl group, ${ }^{5}$ (b) piperidinium- and pyrrolidinium-based TSILs having 5,6-bis(methylthio)hexyl group, ${ }^{6}$ and (c) a TSIL involving 2-(methylthio)benzoate as an anionic part, ${ }^{7}$ to the best of our knowledge. TSIL (a) having a monothioether group has been reported simply concerning the extraction of $\mathrm{Cd}(\mathrm{II})$ and $\mathrm{Hg}(\mathrm{II}) .^{5}$ On the other hand, TSILs (b) and (c) have been reported to extract selectively some heavy metal ions, such as $\mathrm{Cu}(\mathrm{II}), \mathrm{Ag}(\mathrm{I})$, $\mathrm{Pd}(\mathrm{II}), \mathrm{Hg}(\mathrm{II})$, etc. ${ }^{6,7}$ According to the HSAB concept, the $\mathrm{S}$-donor atom in thioethers is one of the typical "soft bases" having strong affinity with typical "soft acids", including precious metal ions, which are classified as Ahrland's class $b$ metal ions. ${ }^{8}$ Therefore, TSILs having a thioether group would have significant potentials for environmentally-benign selective extraction media of precious metal ions.

On the other hand, it may be important for the practical use of TSILs for the extraction of metal ions that (i) TSIL is simply available for economical preparation, and (ii) the extracted metal ions can be recovered to recycle TSILs. We report here on a highly selective extraction of class $b$ metal ions, and their recovery using a simply available TSIL incorporating a monodentate thioether group, 3-thiapentylpyridinium bis(trifluoromethylsulfonyl)imide ([3-TPPy][NTf 2 , Fig. 1). Here, a pentyl group in a well-known IL, pentylpyridinium
\end{abstract}

$\dagger$ To whom correspondence should be addressed. E-mail: chayama@konan-u.ac.jp (K. C.); iwatsuki@center. konan-u.ac.jp (S. I.) bis(trifluoromethylsulfonyl)imide $\quad\left([\mathrm{PPy}]\left[\mathrm{NTf}_{2}\right]\right),{ }^{9} \quad$ simply changes into a 3-thiapentyl group.

The introduction of the 3-thiapentyl group to the pyridine nitrogen was achieved simply by heating an equimolar mixture of pyridine and 2-chloroethyl ethyl sulfide under an inert atmosphere. Because pyridine acts as a solvent as well as a reactant, this procedure does not need any other synthetic solvent. After evaporation of the unreacted reagents, the crude product, 3-thiapentylpyridinium chloride ([3-TPPy]Cl), was treated with aqueous $\mathrm{Li}\left(\mathrm{NTf}_{2}\right)$ to generate [3-TPPy] $\mathrm{NTf}_{2}$ ]. Exhaustive washing with water and drying in vacuo afforded analytically pure [3-TPPy] $\left[\mathrm{NTf}_{2}\right]$. It was a water-insoluble liquid with a density of $\rho=1.48 \mathrm{~g} \mathrm{~cm}^{-3}$ at room temperature, whose physical properties are very similar to those of unfunctionalized [PPy] $\left[\mathrm{NTf}_{2}\right]\left(\rho=1.41 \mathrm{~g} \mathrm{~cm}^{-3}\right)$.

The water/TSIL extraction experiments of metal ions were carried out by shaking a mixture of $1 \mathrm{~mL}$ of [3-TPPy] $\left[\mathrm{NTf}_{2}\right.$ ] and $2 \mathrm{~mL}$ of the aqueous phase containing each metal ion $(0.50 \mathrm{mM})$ as a sulfate salt and $\mathrm{pH}$ buffer $(200 \mathrm{mM})$. Table 1 gives the extraction efficiencies $(\% E)$ of various metal ions, associating with the data of unfunctionalized [PPy] $\left[\mathrm{NTf}_{2}\right]$. [3TPPy] $\left[\mathrm{NTf}_{2}\right]$ extracted class $b$ metals, such as $\mathrm{Ag}(\mathrm{I}), \mathrm{Cu}(\mathrm{I})$, $\mathrm{Pd}(\mathrm{II})$, and Pt(II), almost quantitatively. However, this TSIL did not extract any other metal ions classified into class $a b$ as well as class $a$. Such extraction selectivity strongly suggests that [3TPPy] $\left[\mathrm{NTf}_{2}\right]$ has a significant potential for the selective extraction of class $b$ metal ions including precious metal ions. From the fact that unfunctionalized $[\mathrm{PPy}]\left[\mathrm{NTf}_{2}\right]$ did not any

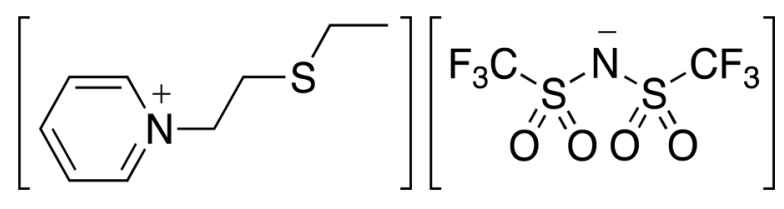

Fig. 1 Structure of [3-TPPy][NTf 2 . 
Table 1 Extraction efficiencies $(\% E)$ of various metal ions ${ }^{\mathrm{a}}$

\begin{tabular}{|c|c|c|c|}
\hline \multirow{2}{*}{ Metal ion } & \multirow{2}{*}{$\begin{array}{l}\text { Ahrland's } \\
\text { classification }\end{array}$} & \multicolumn{2}{|c|}{$\% E^{\mathrm{b}}$} \\
\hline & & {$[3-\mathrm{TPPy}]\left[\mathrm{NTf}_{2}\right]$} & {$[\mathrm{PPy}]\left[\mathrm{NTf}_{2}\right]$} \\
\hline $\operatorname{Ag}(\mathrm{I})$ & class $b$ & $>99$ & 0 \\
\hline $\mathrm{Cu}(\mathrm{I})^{\mathrm{c}}$ & class $b$ & $>99$ & 0 \\
\hline $\operatorname{Pd}(\mathrm{II})^{\mathrm{d}}$ & class $b$ & $>99$ & 0 \\
\hline $\operatorname{Pt}(\mathrm{II})^{\mathrm{e}}$ & class $b$ & $>99$ & 0 \\
\hline Mn(II) & class $a b$ & 0 & 0 \\
\hline $\mathrm{Co}(\mathrm{II})$ & class $a b$ & 0 & 0 \\
\hline $\mathrm{Ni}(\mathrm{II})$ & class $a b$ & 0 & 0 \\
\hline $\mathrm{Zn}(\mathrm{II})$ & class $a b$ & 0 & 0 \\
\hline $\mathrm{Sn}(\mathrm{II})$ & class $a b$ & 0 & 0 \\
\hline $\mathrm{Li}(\mathrm{I})$ & class $a$ & 0 & 0 \\
\hline $\operatorname{Mg}(\mathrm{II})$ & class $a$ & 0 & 0 \\
\hline $\mathrm{Ca}(\mathrm{II})$ & class $a$ & 0 & 0 \\
\hline $\operatorname{Sr}(\mathrm{II})$ & class $a$ & 0 & 0 \\
\hline
\end{tabular}

a. Initial concentration of metal ion $=0.50 \mathrm{mM}$ (sulfate salt) and $\mathrm{pH}$ $=1.0$ in aqueous phase.

b. Determined on the basis of the mole ratio of the metal ion between before and after extraction in the aqueous phase.

c. $\mathrm{pH}=5.5$ in the aqueous phase containing $\left(\mathrm{NH}_{3} \mathrm{OH}\right)_{2} \mathrm{SO}_{4}(33 \mathrm{mM})$ to suppress the oxidation of $\mathrm{Cu}(\mathrm{I})$.

d. $\mathrm{pH}=0.5$ in the aqueous phase.

e. $\mathrm{K}_{2} \mathrm{PtCl}_{4}$ was used as a $\mathrm{Pt}(\mathrm{II})$ salt

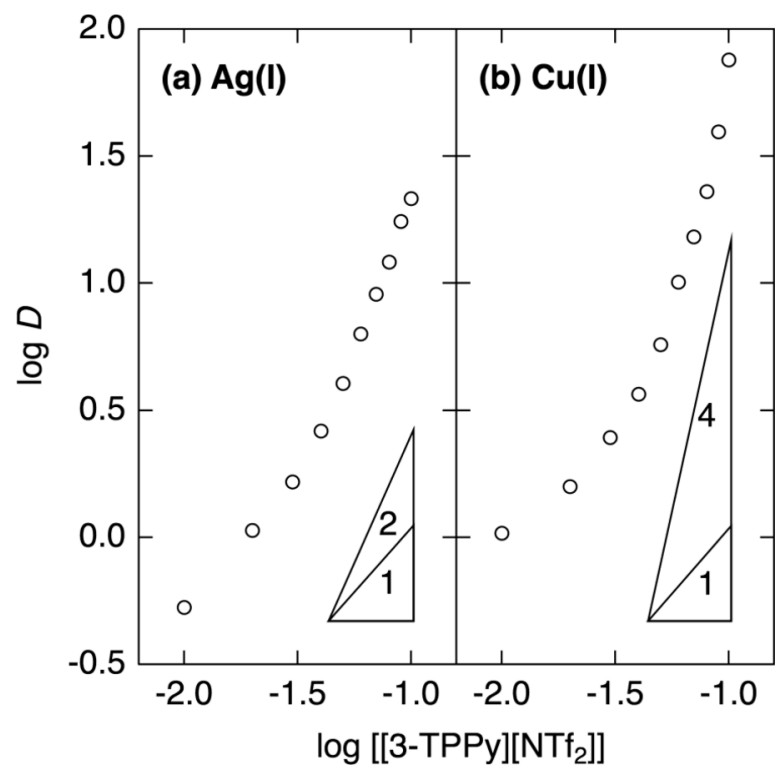

Fig. 2 Dependence of the distribution ratio $(\log D)$ on the [3-TPPy] [NTf 2$]$ concentration $\left(\log \left[[3-\mathrm{TPPy}]\left[\mathrm{NTf}_{2}\right]\right]\right)$ in the [PPy][NTf2] phase for the extractions of (a) $\mathrm{Ag}(\mathrm{I})$ and (b) $\mathrm{Cu}(\mathrm{I})$ ions. Conditions of the aqueous phase: initial concentration of metal ion $=0.50 \mathrm{mM} ; \mathrm{pH}=(\mathrm{a})$ 5.0 and (b) 5.5 using acetate buffer $(200 \mathrm{mM})$. The aqueous phase of $\mathrm{Cu}$ (I) contains $\left(\mathrm{NH}_{3} \mathrm{OH}\right)_{2} \mathrm{SO}_{4}$ to suppress the oxidation to $\mathrm{Cu}(\mathrm{II})$.
Table 2 Efficiencies of the extraction (\%E) and recovery $(\% R)$ of $\mathrm{Ag}(\mathrm{I})$ and $\mathrm{Cu}(\mathrm{I})$ ions

\begin{tabular}{ccc}
\hline \multirow{2}{*}{$\begin{array}{c}\text { Extraction-recovery } \\
\text { cycle }^{\mathrm{a}}\end{array}$} & \multicolumn{2}{c}{$\% E$ and $\% R^{\mathrm{b}}$} \\
\cline { 2 - 3 } & $\operatorname{Ag}(\mathrm{I})^{\mathrm{c}}$ & $\mathrm{Cu}(\mathrm{I})^{\mathrm{d}}$ \\
\hline 1st extraction & 52 & 72 \\
2nd extraction & 50 & 69 \\
3rd extraction & 51 & 72 \\
1st recovery & 91 & 94 \\
2nd recovery & 109 & 91 \\
\hline
\end{tabular}

a. Extraction was carried out from the aqueous phase $(1 \mathrm{~mL})$ containing $0.50 \mathrm{mM}$ of metal ion into $50 \mathrm{mM}$ of [3-TPPy] $\left[\mathrm{NTf}_{2}\right]$ in $[\mathrm{PPy}]\left[\mathrm{NTf}_{2}\right]$ as an IL phase $(2 \mathrm{~mL})$. Recovery was carried out from the IL phase containing extracted metal ion into the aqueous phase containing $200 \mathrm{mM}$ of thiourea. The metal ion-recovered IL phase was used for the next extraction after washing with water.

b. The $\% E$ was determined on the basis of the mole ratio of the metal ion between before and after extraction in the aqueous phase. The $\% R$ was determined on the basis of the mole ratio of the metal ion between before and after recovery in the IL phase.

c. The $\mathrm{pH}$ of the aqueous phase was adjusted to $\mathrm{pH}=1.0$ using sulfuric acid for the extraction, and $\mathrm{pH}=1$ using nitric acid for the recovery.

d. The $\mathrm{pH}$ of the aqueous phase was adjusted to $\mathrm{pH}=5.5$ for the extraction and $\mathrm{pH}=6$ for the recovery using acetate buffer. The aqueous phase for the extraction contains $\left(\mathrm{NH}_{3} \mathrm{OH}\right)_{2} \mathrm{SO}_{4}(33 \mathrm{mM})$ to suppress the oxidation of $\mathrm{Cu}(\mathrm{I})$. IL phase for the extractions of $\operatorname{Ag}(\mathrm{I})$ and $\mathrm{Cu}(\mathrm{I})$ is shown in Fig. 2. The concentration of [3-TPPy] $\left[\mathrm{NTf}_{2}\right]$ was adjusted by diluting with [PPy] $\left[\mathrm{NTf}_{2}\right]$ as a non-extracting IL (cf. Table 1). Both slopes in Fig. 2 decrease to almost unity at lower TSIL concentrations, indicating that the composition ratio of the extracted species is a metal ion:TSIL $=1: 1$. On the other hand, both slopes in Fig. 2 increase with an increase of the TSIL concentrations; the composition ratio increased to $\mathrm{Ag}(\mathrm{I}): \mathrm{TSIL}=$ 1:2 (Fig. 2a) and $\mathrm{Cu}(\mathrm{I}): \mathrm{TSIL}=1: 4$ (Fig. 2b). Since the thioether group of [3-TPPy] $\left[\mathrm{NTf}_{2}\right]$ can coordinate to the metal center as a monodentate S-donor ligand according to the structure (Fig. 1),

metal ions (Table 1), the extraction by [3-TPPy][NTf 2 was considered to occur through the coordination of the S-donor atom to class $b$ metal ions. It is of note that the $\mathrm{Pt}(\mathrm{II})$ species in
the aqueous phase were also extracted almost quantitatively, though the aqueous phase was prepared by dissolving $\mathrm{K}_{2} \mathrm{PtCl}_{4}$ in a "chloride-free" acidic buffer. The main $\mathrm{Pt}(\mathrm{II})$ species are under the present condition, whose formation ratios were estimated on the basis of reports concerning the equilibria of $\left.\mathrm{P}^{2} \mathrm{Cl}_{4}\right]^{2-}$ in a strongly acidic aqueous solution ${ }^{10}$ (detailed
estimations are provided in Supporting Information). Therefore, the extraction of $\mathrm{Pt}(\mathrm{II})$ may also occur through S-donor ligand is substituted by an S-donor atom.

extraction systems using 1-(3-thiapentyl)-3-methylimidazolium for class $a \mathrm{Mg}$ (II). ${ }^{11}$ This result predicts that the 3-thiapentyl above.

it was considered that the number of coordinating S-donor atoms in the extracted metal complexes depends on the TSIL concentration. Therefore, both $\mathrm{Ag}(\mathrm{I})$ and $\mathrm{Cu}(\mathrm{I})$ are extracted even at low TSIL concentrations through the formation of the mono-S-coordinated metal complexes, whereas at high TSIL concentrations this occurs through the formation of bis- and tetra-S-coordinated complexes for $\mathrm{Ag}(\mathrm{I})$ and $\mathrm{Cu}(\mathrm{I})$, respectively, both of which are in line with the general coordination numbers 
of the corresponding metal ions. ${ }^{12}$ The extraction behaviors of $\mathrm{Pd}(\mathrm{II})$ and $\mathrm{Pt}(\mathrm{II})$ were rather complicated, because the species in the aqueous phase changed depending on the existing anion(s), such as $\mathrm{Cl}^{-}$, as mentioned for the $\mathrm{Pt}(\mathrm{II})$ system. Thus, the further detailed analyses are needed.

$\mathrm{Ag}(\mathrm{I})$ and $\mathrm{Cu}(\mathrm{I})$ ions in the IL phase containing [3-TPPy] $\left[\mathrm{NTf}_{2}\right]\left(50 \mathrm{mM}\right.$ in $\left.[\mathrm{PPy}]\left[\mathrm{NTf}_{2}\right]\right)$ were recovered almost quantitatively $(>90 \%)$ by treating with the acidic aqueous phase containing $200 \mathrm{mM}$ of thiourea, as shown in Table 2. After washing the metal ion-recovered IL phase with water, the resulting IL phase could again extract $\mathrm{Ag}(\mathrm{I})$ and $\mathrm{Cu}(\mathrm{I})$ ions in comparable $\% E$ with the first extraction (Table 2). This result strongly suggests that [3-TPPy] $\left[\mathrm{NTf}_{2}\right]$ can be recycled in the extraction-recovery processes of class $b$ metal ions.

Thus, the present monothioether-functionalized pyridinium TSIL as a good extraction medium of class $b$ metal ions would be useful from the points of green sustainability and safety, because (i) ILs are incombustible and nonvolatile, ${ }^{1-4}$ (ii) the pyridinium-based TSILs can be prepared without another synthetic solvent, and (iii) the TSIL can be recycled. Further investigations, such as concerning the detailed extraction behaviors and the preparation of the other effective TSILs, are in progress in our research group.

\section{Acknowledgements}

This work was supported in part by JSPS KAKENHI Grant Numbers 20550089 (to K. C.) and 15K05551 (to S. I.).

\section{Supporting Information}

Experimental details such as the preparation of ILs in the present study and the extraction procedures, as well as detailed estimations of $\mathrm{Pt}(\mathrm{II})$ species in acidic aqueous solution of
$\mathrm{K}_{2} \mathrm{PtCl}_{4}$ are given in Supporting Information. This material is available free of charge on the Web at http://www.jsac.or.jp/ analsci/.

\section{References}

1. S. Tang, G. A. Baker, and H. Zhao, Chem. Soc. Rev., 2012, $41,4030$.

2. X. Sun, H. Luo, and S. Dai, Chem. Rev., 2012, 112, 2100.

3. "Ionic Liquids in Synthesis", ed. P. Wasserscheid and T. Welton, 2nd ed., 2008, Wiley-VCH, Weinheim.

4. J. P. Hallett and T. Welton, Chem. Rev., 2011, 111, 3508.

5. (a) A. E. Visser, R. P. Swatloski, W. M. Reichert, R. Mayton, S. Sheff, A. Wierzbicki, J. H. Davis, Jr., and R. D. Rogers, Chem. Commun., 2001, 135; (b) A. E. Visser, R. P. Swatloski, W. M. Reichert, R. Mayton, S. Sheff, A. Wierzbicki, J. H. Davis, Jr., and R. D. Rogers, Environ. Sci. Technol., 2002, 36, 2523.

6. (a) J.-M. Lee, Fluid Phase Equilib., 2012, 319, 30; (b) N. Papaiconomou, J.-M. Lee, J. Salminen, M. von Stosch, and J. M. Prausnitz, Ind. Eng. Chem. Res., 2008, 47, 5080.

7. (a) L. Fischer, T. Falta, G. Koellensperger, A. Stojanovic, D. Kogelnig, M. Galanski, R. Krachler, B. K. Keppler, and S. Hann, Water Res., 2011, 45, 4601; (b) A. Stojanovic, D. Kogelnig, L. Fischer, S. Hann, M. Galanski, M. Groessl, R. Krachler, and B. K. Keppler, Aust. J. Chem., 2010, 63, 511.

8. S. Ahrland, J. Chatt, and N. R. Davies, Quart. Rev. Chem. Soc. [London], 1958, 12, 265.

9. Q.-S. Liu, M. Yang, P.-F. Yan, X.-M. Liu, Z.-C. Tan, and U. Welz-Biermann, J. Chem. Eng. Data, 2010, 55, 4928.

10. (a) L. I. Elding, Acta Chem. Scand., 1970, 24, 1331; (b) L. I. Elding and I. Leden, Acta Chem. Scand., 1966, 20, 706.

11. Unpublished results.

12. F. A. Cotton, G. Wilkinson, and P. L. Gaus, "Basic Inorganic Chemistry", 3rd ed., 1995, Wiley, New York. 